\title{
Psikanalitik Yaklaşım Çerçevesinde Nevrotik İhtiyaçlar Çözümlemesi: Kayıp Kız Filmi
}

\author{
Neurotic Needs Analysis Within The Scope of Psychoanalytic Approach: Gone Girl Movie \\ İbrahim Y1ldiz ${ }^{\mathrm{a}, *}$ \\ ${ }^{a}$ Öğr. Gör., İstanbul Üniversitesi, Rektörlük, Kurumsal İletişim Koordinatörlüğü, 34452, İstanbul/Türkiye. \\ ORCID: 0000-0002-2542-389X
}

\begin{tabular}{l} 
MAKALE BİLGİSİ \\
Makale Geçmişi: \\
Başvuru tarihi: 13 Kasım 2019 \\
Düzeltme tarihi: 02 Mart 2020 \\
Kabul tarihi: 19 Mart 2020 \\
\hline Anahtar Kelimeler: \\
Psikanalitik, \\
Temel Kayg1, \\
Nevrotik İhtiyaçlar \\
Sinema
\end{tabular}

\section{A RTICLE INFO}

Article history:

Received 13 Kasım 2019

Received in revised form 02 March 2020

Accepted 19 March 2020

\section{Keywords:}

Psychoanalytic,

Basic Anxiety,

Neurotic Needs,

Cinema

\begin{abstract}
ÖZ
Psikolojide çok sayıda bilimsel çalışmada yer alan psikanaliz, Freud ve onun öğretilerinden gelişen bir yaklaşım olarak karşımıza çıkmaktadır. Freud'un kişilik yapısı üzerine biyolojik sebeplerle sınırlı yaklaşımına karşı çıkan psikanaliz kuramcısı Karen Horney, kişilik gelişiminde ve davranışlarda doğuştan gelen özelliklerinden ziyade çocukluk döneminde yaşanan deneyimler ve toplumsal etkilere odaklanmıştır. Horney'in psikanalitik yaklaşıma katkısı olan nevrozlar ve insan gelişimi çalışmanın temelini oluşturmaktadır. İnsan davranışlarına yönelik çözümlemelerde psikanalitik yaklaşım çerçevesinde filmlerin içerik malzemesi ve karakterleri psikanalitik veriler olarak değerlendirilmektedir. Nevrotik karakterler üzerine film çözümlemesine katk1 amacı taşıyan çalışma, Horney'in nevrotik ihtiyaçlar ve nevrotik eğilimler yaklaşımından hareketle, yönetmenliğini David Fincher'in yaptığı "Kayıp Kız (Gone Girl)” filminin nevrotik karakter çözümlemesini içermektedir. Çalışmada incelenen karakterin, Horney’in kuramında belirttiği nevrotik eğilimlerle örtüşen davranışlar sergilediği sonucuna varılmıştır.
\end{abstract}

\section{A B S T R AC T}

Psychoanalysis, which has taken its place among many scientific studies in psychological history, appears as an approach of Freud and his thoughts. Karen Horney, who objects to Freud's limited approach over his characteristic structure due to biological reasons, prioritized childhood experiences and their social impact instead of inborn qualities. This study is based on neurosis and human development, which contributes to Horney's psychoanalytic approach. The context and characters of the movies are also considered data for an psychoanalytic approach of human behavior. This study contributes to analysis of neurotic characters from movies, including an analysis of neurotic characters from David Fincher's 'Gone Girl.' The analyzed character in this study is shown to showcase neurotic tendencies as mentioned in Horney's approach.

\section{Giriş}

İnsanlar gelişim süreçleri boyunca, yaşadıkları toplumda diğer insanlarla sürekli etkileşim halindedir ve bu etkileşim sırasında çeşitli davranış kalıpları geliştirir. İnsan gelişimi ve davranışı teorisi olarak tanımlanan psikanalizin başlangıcını Sigmund Freud'un ortaya koyduğu yaklaşımlar oluşturur. Freud'un ardından bu yaklaşımın temsilcileri tarafından kişilik, kişilik gelişimi ve davranışlar açısından geliştirilen farklı görüşler bulunmaktadır. $\mathrm{Bu}$ yaklaşımların ortak özelliği, çocukluk döneminde yaşanan deneyimlerin insan kişiliğinin gelişmesinde etkili olduğu düşüncesidir (Budak, 2000: 619).

Psikanalitik yaklaşım temsilcilerinden Karen Horney, insan davranışlarını açıklamada içgüdüsel sebeplere vurgu yapan Freud'un görüşünü genetik psikoloji ile sınırlandırılmış bir kuram olarak değerlendirir ve bunun aşılması gerektiğini belirtir (Doruk, 2015: 166). Horney, insan davranışlarını aile içi ilişkilerde yaşanan aksaklıkların bir sonucu olarak görür ve sosyokültürel faktörlerin de bu öğrenme süreci üzerinde önemli bir etkisi olduğunu savunur. Horney ayrıca,

\footnotetext{
* Sorumlu yazar/Corresponding author.

e-posta: iyildiz1@istanbul.edu.tr
} 
Freud'dan farklı olarak, çocukluk yılları ile yetişkin davranışları arasında doğrudan bir ilişki kurma imkânının sınırlı olduğunu belirtir ve kişiliğin gelişiminin çocuklukta tamamlanacağı düşüncesine itiraz eder. Ona göre bu süreç ilerleyen dönemlerde de devam etmektedir. Çünkü insanların, davranışlarını geliştirmelerine sebep olacak başka olaylar yaşaması muhtemeldir (Geçtan, 1996: 237-238).

Horney, kişiliğin yapısı ve gelişimi konularının yanında nevroz, psikoterapi ve kadın psikolojisi üzerine de çalışmalar yapmıştır. Freud'un düşüncelerinden ayrılmaktan ziyade nevrozun oluşumuna ve sağaltımına ilişkin bizzat kendisine ait yaratıcı ve özgün bir kuram ortaya koymuştur (İnanç ve Yerlikaya, 2012: 89-90). Çalışmada Horney'in nevrozlar ve insan gelişimi üzerine ortaya koyduğu nevrotik ihtiyaçlar ve nevrotik eğilimler yaklaşımı, ilgili kavramlarla birlikte ele alınmıştır. Söz konusu filmde yer alan karakterin nevrotik eğilime sahip olup olmadığını belirlemek çalışmanın temel problemini oluşturmaktadır. Bu çerçevede Kayıp Kız (Gone Girl) filminin psikanalitik yaklaşımla nevrotik karakter çözümlemesi amaçlanmıştır. Söz konusu yaklaşım ve ilgili kavramlar bu çalışmanın sınırlarını oluşturmaktadır.

\section{Nevrozlar ve İnsan Gelişimi}

Kişilik kuramları çerçevesinde Freud'un tanımıyla “organik veya nörolojik kökenli olmayan, gerçeklikle ilişkinin, bir miktar çarpıtmaya uğrasa bile henüz kaybolmadığı ruhsal kökenli rahatsızlıkların ortak adı" olarak tanımlanan nevroz, Karen Horney tarafindan, bir derece sorunu olarak görülür (Budak, 2000: 535; İnanç ve Yerlikaya, 2012: 90). Horney nevrozu "çatışan eğilimler için uzlaşmalı çözümler bulmaya yönelik girişimler tarafindan yaratılan ruhsal bir hastalık" olarak tanımlar (Kiraz, 2015: 138). Horney'e göre nevrotik süreç, insan gelişiminin özel bir biçimidir. İnsan gelişiminin içerdiği yapıcı enerjinin boşa harcanması sebebiyle Horney bu süreci talihsiz bir süreç olarak görür. (Horney, 2015: 21)

Freud'un bazı görüşlerini eleştiren Horney, kişiliğin şekillenmesinde Freud'un içgüdüsel görüşlerinin aksine kültürel etkilerin önemine vurgu yapmıştır. İnsanın sadece haz ilkesi ile değil, güvenlik ve tatmin ilkeleriyle yönetildiğini savunmuştur. Temelde bireyin bilinmez tehlikelerle dolu vahşi bir yaşamda kendi yolunu bulma çabası içerisinde olduğunu ve bu vahşi yaşamın, içgüdüler veya anatomi tarafindan değil, toplum tarafindan yaratıldığını belirtmiştir. (Feist ve Feist, 2008: 172). İnsan davranışlarını açıklamada aile içerisinde yaşanan ilişkilerdeki problemlere ve sosyo-kültürel etkenlere odaklanan Horney, insanların birbirleriyle ya da toplumla olan ilişkisinin ve ebeveynlerin çocuklarıyla olan ilişkisinin önemine değinir. Buna göre davranışlar, insanın çevresiyle kurduğu ilişkilerinde geliştirmiş olduğu tepkilerin örgütlenmiş örüntülere dönüşmesiyle oluşur. İnsan yaşamının erken döneminde sınırlı olan bu tepkiler daha sonra geniş ilișki alanlarına yönelir. İnsanın hayatı boyunca geliştirdiği algılar, değerler, duygular ve düşüncelerin etkileşimi, davranışlarının belirleyicileri olur (Geçtan, 1996: 237-238).

\subsection{Temel Kayg1}

Horney'in teorisinin altında temel kaygl (basic anxiety) kavramı yer almaktadır. Temel kaygı, bir çocuğun yalnız kalmaktan, çaresiz ve güvensiz durumda olmaktan korkmasıdır. Temel kaygının ortaya çıkmasında çocuğun ebeveynleri ile olan ilişkilerindeki sıcaklık, istikrar, saygı veya katılım eksikliği gibi sorunlar etkili olur (Friedman ve Schustack, 2016: 86). Ebeveynle çocuk arasında güvenli bir ilişkiyi zedeleyen her türlü davranış kaygıya sebep olabilir. $\mathrm{Bu}$ yüzden temel kayg1 doğuştan gelen bir duygu değil, sosyal ve çevresel etkenler sonucu ortaya çıkan bir duygudur (Schultz ve Schultz, 2002: 579).

Olumsuz çevresel faktörlerden herhangi birine sürekli maruz kalan çocukların temel bir kaygı yaşayacağını vurgulayan Horney temel kaygıyı; potansiyel olarak düşmanca olduğu düşünülen bir dünyada hissedilen yalnızlık ve çaresizlik duyguları olarak tanımlamaktadır (Shatz, 2004: 1255). Horney, temel kaygı yaşayan çocukların, acımasız olarak algıladıkları sosyal çevrelerinden korktuklarını belirtir. Bu çocuklar ayrıca ebeveynleri ve diğer yetişkin otorite figürleri tarafından özgürlüklerinin alındığını ve mutluluklarının önlendiğini düşünürler. Böylece kendi özgüvenleri sürekli olarak zayıflar (Ryckman, 2008: 146).

Kaygının tehlikeye dönük coşkusal bir tepki olduğunu ve bu nedenle korkuyla benzeştiğini söyleyen Horney, kaygının yaygın ve belirsiz niteliğinden ötürü korkudan farklı olduğunu belirtir (Horney, 1994: 143). Diğer bir ifadeyle korkuya sebep olan tehlike açık ve nesneldir. Ancak kaygıya sebep olan tehlike gizli ve öznel bir nitelik taşır (Geçtan, 2003: 166).

Çocukluk yıllarında ebeveynle çocuk arasındaki ilişkiye yönelen Horney, temel kaygının oluşmasında düşmanca dürtülerin önemli olduğunu belirtir. Ebeveynlerin çocuğun güvenlik ihtiyacını tatmin edebildiği gibi engelleyebileceğini de savunur. Buna göre, ebeveynler çocuğun güvenlik ihtiyacını yeterince karşılayamadığı durumlarda çocuk, ebeveynlerine karşı düşmanlık duyguları geliştirir. Oluşan bu tepkisel düşmanlık çocuk için daha fazla kaygıya sebep olabilir ve böylece düşmanlıkla kaygı arasında döngüsel bir etkileşim meydana gelir (İnanç ve Yerlikaya, 2012: 91). Horney, güvenlik ihtiyac1, emniyet ve korkudan emin olma durumunun insan davranışlarının güdüleyici gücünü oluşturduğunu belirtir (Schultz ve Schultz, 2002: 579).

Horney'e göre, çocukluk döneminde yaşanan temel kaygı nevrozda en önemli etkendir. Çocuğun problemli ortamlarda büyümesi durumunda kaygı yaşayacağını belirten Horney, saldırganlığın doğuştan gelen bir özellik olmadığına inanır ve kişinin güven duygusunu korumak amaciyla geliştirdiği bir tutum olarak kabul eder (Doruk, 2015: 167). Ayrıca temel kaygı kişi için dayanılması zor bazı özellikler taşıyabilir. Bu özelliklerden ilki çaresizlik duygusudur. Tehlike karşısında normal insanlar etkin ve cesaretli davranabilirken, kaygı sahibi kişiler çaresizlik duyabilirler. Temel kaygının diğer özelliği ise mantıkdışı olmasıdır. Mantıkdışı etkenlerin denetiminde kalmak dayanılması güç bir durum oluşturabilir. Temel kaygı taşıyan insanlar korkularının ve savunma mekanizmalarının esiri olur. Davranışlarının normal olduğunu düşünen bu insanlar, kendilerinde bir bozukluk olduğu fikrini reddederler (Geçtan, 2003: 166167).

Temel kaygı tek başına nevrozu ifade etmez. Temel kaygı, nevrozun herhangi bir dönemde ortaya çıkabileceği bir zemini ifade eder (İnanç ve Yerlikaya, 2012: 91). Horney, nevrotik gelişmenin sebebi olarak yabancılaşma, düşmanlık, korku ve azalan özgüven duygularını görür, ancak bunların 
tek başına nevrozu oluşturmadığını söyler. Potansiyel olarak tehlikeli görülen bir dünyada temel kaygıyı oluşturan bu duyguların birleşimi nevrozun gelişebileceği zemini oluşturur (Horney, 1994: 127). Horney'e göre insanlarla ilişkilerinde kendilerine zarar veren bir tutum içerisinde sıkışmış olmaları nevrotik kişilerin en temel özelliğidir (Burger, 2006: 173).

\subsection{Temel Kaygıya Karşı Savunma Yöntemi Olarak Nevrotik İhtiyaçlar}

Ebeveyn ve çocuk arasındaki ilişkide temel kaygı ortaya çıktığında çocuk güvensizlik duygularıyla mücadele edebilmek için bazı davranış biçimleri geliştirir ve çevrenin beklentilerine yönelik kendi kişiliğini oluşturur. Söz konusu davranış biçimlerinden birisinin kişiliğin değişmez bir parçası haline gelmesine nevrotik ihtiyaç (neurotic need) denir. Nevrotik ihtiyaçlar temel kaygıya karşı bir savunma yöntemidir. Horney, nevrotik ihtiyaçlar olarak tanımladığı davranış biçimlerinin normal insanlar tarafından da geçerli olabileceğini ancak onlar için aşırı ve baskın bir yapıda olmadığını belirtir. Buna karşın nevrotikler için söz konusu davranışlardan biri, kişiliği ile bütünleşir ve baskın bir yapıda tüm davranışlarını biçimlendirir. Horney bu kişileri nevrotik olarak tanımlar. Horney, nevrotik kişilerin kaygıyla baş edebilmede geliştirdikleri on maddelik nevrotik ihtiyaçları şu şekilde açıklar (Schultz ve Schultz, 2002: 580; İnanç ve Yerlikaya, 2012: 93-95; Geçtan, 1996: 254-255):

Sevgi ve onay için nevrotik ihtiyaç: Başkalarını hoş tutmaya ve onların isteklerine uygun davranmaya yönelik ihtiyaçtır. Başkalarının kendisi hakkında iyi düşünceye sahip olmasını isterler ve reddedilmeye karşı hassastırlar. Bireyin kendisinden ziyade başkalarının görüşleri önemlidir.

Yaşamını yönetecek bir ortağa duyulan nevrotik ihtiyaç: Yaşama dair yükün sorumluluğunu üstlenecek bir eşe duyulan ihtiyaçtır. Sevgi tüm sorunların çözüm kaynağı olarak görülür ve çok önemsenir. Bu kişiler terk edilmekten ve yalnız kalmaktan korku duyar.

Yaşamını dar sınırlar içinde tutmaya yönelik nevrotik ihtiyaç: Başkalarından bir şey beklememe ve göze çarpmama eğilimindedirler. İkinci planda olmayı tercih ederler. Beceri ve potansiyellerini küçümseme eğiliminde olan bu insanlar azla yetinir, aşırı isteklerden ve bu istekleri dile getirmekten kaçınırlar.

Güç kazanmak için nevrotik ihtiyaç: Başkalarını küçük düşürmeye yönelik güç kazanma isteğindedirler. Diğer insanların bireyselliğine, onuruna ve duygularına karşı saygısızdırlar. İstem gücüyle her şeyi elde edebileceğine inanan bu insanların ilgilendikleri tek şey başkalarının boyun eğmesidir.

Başkalarını sömürmeye yönelik nevrotik ihtiyaç: Bu kişiler diğer insanları, kullanmaya elverişli olmaları temelinde değerlendirirler. $\mathrm{Bu}$ şekilde hem bağımlılık ihtiyaçlarına hem de düşmanca duygularına doyum sağlamış olurlar.

Saygınlık kazanmaya yönelik nevrotik ihtiyaç: Popüler olma çabasındaki bu insanlar ilgiyi kendi üzerlerine çekerek önemli biri görüntüsü vermeye çalışırlar. $\mathrm{Bu}$ insanlar saygınlığını yitirme korkusu duyarlar.

Başkalarının hayranlığını kazanmaya yönelik nevrotik ihtiyaç: Kişinin kendisini abartılı şekilde değerli görmesi ve bunun diğerleri tarafindan hayranlıkla onaylanmasına duyduğu ihtiyaçtır. Bu kişiler oldukları gibi değil, görünmek istedikleri şekilde görünürler.

Başarı kazanmaya yönelik nevrotik ihtiyaç: Kişinin diğer insanları yenme ve üstün durumda olma arzusu içinde olmasıdır. Bu kişiler temel bir güvensizlik duyduğu için sürekli ilerleme ve başarı kazanma isteğindedirler. Başarısızlık ve küçük düşürülme korkuları taşırlar.

Bă̆ımsızlı̆̆a ve kendine yeterli olmaya yönelik nevrotik ihtiyaç: Başkalarıyla kurduğu samimi ilişkilerde başarısız olmuş kişilerin insanlardan uzaklaşarak tek başına ayakta durabildiğini ispatlama çabasına yönelik bir ihtiyaçtır. Bağlılıktan, yakınlıktan ve sevgiden kaçarlar.

Kusursuz olmaya ve eleştiriye karşı savunmaya yönelik nevrotik ihtiyaç: Bu kişiler yanlış yapmaktan korkarlar. Kendi hata ve zayıflıklarını gizleme ve başkaları tarafından fark edilmesini önleme gayretindedirler. Yetersizlik, eleştiri ve suçlanma korkusu yaşarlar.

\subsection{Nevrotik Eğilimler}

Horney, teorisini geliştirdikçe nevrotik ihtiyaçları daha sonraki yazılarında nevrotik eğilimler (neurotic trends) olarak açıkladığı üç genel kategoride toplamıştır. Söz konusu nevrotik eğilimler, insanlara yönelme (moving toward people), insanlara karşı olma (moving against people) ve insanlardan uzaklaşma (moving away from people) olarak üç gruba ayırdığı temel kaygıyla mücadele stratejileridir (Feist ve Feist, 2008: 176).

Horney’e göre nevrotik eğilimlerin en belirgin özelliği, bu eğilimlerin kendini iki temel yoldan belli eden zorlanımlı yapısıdır. Buna göre ilk gösterge, bu eğilimlerin amaçları, koşul, durum ya da nesne ayrımı olmaksızın izlenmesidir. Sevgi ihtiyacı olan kişi bunu dostundan düşmanına, işvereninden kunduracısına kadar görmek ister. Diğer taraftan bu eğilimlerde gerçeklik ve gerçek öz-çıkar durumu dikkate almaksızın ilerler. Örneğin yaşamın tüm yükünü taşımasını beklediği eşinin kendisi için uygun olup olmadığı ya da onu gerçekten sevip sevmediğinin farkında olmayabilir. Nevrotik eğilimlerin zorlanımlı yapısının ikinci göstergesi ise, bunların engellenmelerinden kaynaklanan kaygı tepkisidir. Zorlanımlı eylemleri iç veya dış faktör sebebiyle etkisiz kalması durumunda kişi hayati bir tehlike ile karşılaştığı hissi duyar. Sınırsız özgürlük ihtiyacı duyan kişi, kira sözleşmesi ya da evlilik öncesi nişan gibi bağlayıcılık noktasında korku duyar. Kusursuzluk ya da özgürlükten uzaklaşacağı zaman her şeyini kaybedeceğini düşünür. Zorlanımlı eğilimlerin sorumlusu bu güvenlik değeridir (Horney, 1991: 34-35).

Horney, temel kayg1 ile mücadele geliştirilen nevrotik eğilimlere sahip, uysal tip, saldırgan tip ve yalıktan tip olarak tanımladığı üç nevrotik kişilikten bahseder (Horney, 1995: 39).

Insanlara Yönelme (Uysal Tip): Uyumlu tip olarak bilinen bu bireyler, çaresizliklerini kabullenirler. Temel kaygıya ve korkularına karşı kendilerini güvende hissedebilmek için başkalarının sevgisini kazanmaya çalışırlar ve güçlü olarak algıladıkları kişi veya gruba yönelirler (Coolidge vd., 2001: 1388). Bir eşin yaşamlarını kontrol etmesine yönelik nevrotik ihtiyaçları vardır. Horney'e göre bu bireyler, başkaları tarafından sevilme, takdir edilme, korunma ve yönlendirilme isteği duyarlar. Yetersizliğinden kurtulmak 
için bir eş arar ve onun sağlayacağı güvenlikle bir anlam bulma çabası içerisine girerler (Ryckman, 2008: 151).

Kendi başına sağlayamadığı güveni çevresinden elde etme arayışı ile insanların desteğini almaya yönelik davranışlar sergiler. Ancak bu durum diğer insanlarda yük oluşturduğunda, insanlar bu kişilerden uzaklaşmaya başlar (Geçtan, 1997: 151). Reddedilme onlar için bir felaketi ifade eder. Birey için reddedilme ya da terk edilme ürkütücü bir tehlikedir ve birey tekrar o kişinin saygısını kazanmak için umutsuzca bir çaba içerisine girer (Horney, 1995: 44). Gördükleri ilgi yaşadıkları kaygıyı geçici bir süre gidermiş olsa da daha sonra tekrar benzer tutumlar içerisine girerler (Burger, 2006: 174).

Insanlara Karşı Olma (Saldırgan Tip): İnsanlara karşı olma eğilimindeki saldırgan tip herkesin düşman olduğuna inanır ve bunun aksini kabul etmez. Yaşamı amansız bir kavga gibi gören saldırgan tipin tutumu bazen oldukça açık olmakla beraber çoğunlukla kentli ve soylulara has bir nezaketle ve iyi arkadaşlıkla gizlenir. Uysal tipin aksine korku bileşeni saldırgan tipin kabul etmediği bir şeydir ve güçlü olmaya, güç kazanmaya ya da böyle gözükmeye çalışırlar. (Horney, 1995: 51). Horney, normal insanlardaki güç duygusunun kaynağının, kişinin kendi yetenekleri, düşünce kapasitesi veya olgunluğunun farkına varması olduğunu söyler. Buna karşın nevrotik kişilerin güçlü olmak için gösterdikleri çabanın kaynağının, endişe, nefret ve aşağılık duyguları olduğunu belirtir. Dolayısıyla güce yönelik normal çaba kuvvetten, nevrotik çaba ise zayıflıktan doğar (Yavuzer, 2013: 50). Herkesin düşman olduğuna inanan saldırgan tip için kendi çıkarları peşinde koşmak büyük önem taşır. Kendi çıkarları doğrultusunda başkalarını sömürmek ve onlardan yararlanmak için güçlü bir ihtiyaç tarafindan motive olurlar (Feist ve Feist, 2008: 178).

Horney, saldırgan tiplerin diğer insanları sürekli sömürme eğilimini Freud'un yansıtma kavramıyla benzerlik gösteren dışsallaştırma kavramı ile izah edilebileceğini belirtir. Buna göre bireyler, çocukluk döneminde ebeveynleri ile yaşadıkları sorunlar nedeniyle herkesi kötü ve düşman olarak algılar. Bu alg1 nedeniyle kendilerine bir kötülük yapılmadan önce onlar kötülük yaparlar. Bir kazanç elde edeceklerini görürlerse insanlarla ilişki içerisine girerler (Burger, 2006: 175). Bu yönelime sahip saldırgan tipler kendilerini güçlü, dürüst ve gerçekçi bulurlar. Kendi önermelerine göre her şeyin mantıklı olduğunu düşünürler. Acımasız olmayı bir güç, diğer insanlara yönelik saygısızlığı dürüst bir davranış, kaba bir şekilde kendi çıkarları için hareket etmeyi de gerçekçilik olarak görürler (Horney, 1995: 55).

Insanlardan Uzaklaşma (Yalıktan Tip): Temel çatışmayla baş edebilmede üçüncü yöntem coşkusal yalıtım yoluyla insanlardan uzaklaşmadır. Ancak bu uzaklaşma, yaşamı ciddiye alan normal insanların zaman zaman yalnız kalma isteğinden farklıdır. Horney nevroz belirtisi olarak, kendi iç derinliklerinden kaçmayı ve yapıcı bir yalnızlık yetisinden yoksunluğu sayar. Ona göre, insanlarla ilişki kurmada katlanılması güç bir gerilim duyuluyorsa ve insanlardan uzaklaşma bu gerilimden kurtulmanın bir aracı konumuna gelmişse bu yalnız kalma isteği nevrotik coşkusal yalıtımın göstergesidir. İnsanlardan uzaklaşma eğilimindeki insan tipinin en belirgin özelliği insanlara karşı genel bir yabancılaşmadır. Söz konusu yabancılaşma, insanlara karşı olabildiği gibi nevrotik kişinin kendisine karşı da gelişebilir. Horney bu durumu, coşkusal deneyimlerdeki körelme, kișinin sevgisinin ve nefretinin neye olduğuna, neyi küçümsediğine, ne umduğuna, neden korktuğuna ilişkin belirsizlik olarak açıklar (Horney, 1995: 59-60).

İnsanlardan uzaklaşma eğilimindeki insan tipi bilinçli olarak tamamen kendi kendilerine yeterli olduklarına inanırlar ve başkalarıyla temastan kaçınarak endişeyi azaltmaya ve güvenlik sağlamaya çalışırlar (Ewen, 2003: 119). Bu kişiler insanlarla ilişkilerinde yaşayabileceği acılara karşı insanların yaklaşmasını engelleyici bir duvar örer. İnsanların bunu gerçekleştirmede gereksinim duydukları ihtiyaç, özyeterlilik ihtiyacıdır. Bu ihtiyacın en açık şekilde yansıması becerikli olmaktır. Bu kişiler yalıtımını dengelemede tek yöntem olarak gördüğü beceriklilik sayesinde kimseye ihtiyaç duymayacaklarını düşünürler (İnanç ve Yerlikaya, 2012: 97).

Öz-yeterlilik ve gizlilik insanlardan uzaklaşma eğilimindeki insan tipinin tam bağımsızlık ihtiyacına hizmet eder. Bağımsızlığ 1 , olumlu bir değere sahip olmakla eş tutar (Horney, 1995: 62). İnsanlardan uzaklaşma eğilimdeki yalıtkan tipin bağımsızlık inancının temelini "geri çekilirsem, beni incitemezsiniz" düşüncesi oluşturur. Düşük bir enerji seviyesi, pasif direniş ve yakın ilişkilerden uzaklığın korunması bu tarzın ayırt edici özellikleridir (Feiring, 1983: 3). İnsanlardan uzak olma eğilimindeki kişiler sevgi, ilgi ve arkadaşlık kurmaktan kaçınırlar ve insanlarla çok az iletişime geçecekleri işleri tercih ederler. $\mathrm{Bu}$ kişiler, kaygıdan kaçınmak için kullanılacak en iyi yolun insanlardan uzak durmak olduğu düşüncesine sahiptirler (Burger, 2006: 175).

Hayatın zorlukları karşısında her insan bazı çatışmalar yaşayabilir. Bununla birlikte, normal insanların yaşadığı çatışmalarla nevrotik insanların çatışmaları arasında çarpıcı farklılıklar vardır. Nevrotik kişilerde çatışmalar daha da ciddi durumdadır, çözülemez görünen ikilemler içerir ve her zaman için aşırı bastırılmıştır (Ewen, 2003: 118). Horney, psikolojik açıdan sağlıklı insanların çatışmaları çözmek için üç korunma yöntemini kullanabileceğini belirtir. Ancak bir nevrotik için, kişiliğe egemen olan tek bir stratejinin yaygın olacağına ve bunun sağlıksız bir durum olduğuna işaret eder (Friedman ve Schustack, 2016: 87). Buna göre, nevrotik kişilerde kaygıyla mücadelede kullanılan üç eğilimin her birinde temel kaygı ile ilgili bir bileşen fazla vurgulanmaktadır. İnsanlara yaklaşmada çaresizlik, insanlara karşı olmada düşmanlık, insanlardan uzaklaşmada ise yalıtım öne çıkmaktadır (İnanç ve Yerlikaya, 2012: 97).

\section{4. İdealize Edilmiş Benlik İmgesi}

Horney, nevrotik kişilerin söz konusu eğilimlerde kimlik duygusu arayışına girdiğini, kendisinde olduğuna ya da olması gerektiğine inandığı bir imaj yaratmaya çalıştığını söyler. Bu imaj, yaşamın birey üzerindeki gerçekliğine karşı olarak bilinçli ya da bilinçsiz bir şekilde gerçeklikten büyük oranda uzaklaştırılır. (Horney, 1995: 77) Horney, kendine yabancılaşmış bireyin yaşadığı bu çelişkiyi aşmak için oluşturduğu yanlış kişilik görüntüsünü idealize edilmiş benlik (idealized self-image) kavramıyla açıklar. Buna göre, idealize edilmiş benlik, kişiyi kendi gerçek benliğini anlamaktan uzaklaştıran yanıltıcı bir maskedir. Nevrotik insanlar bu yanılgı sebebiyle yaşadıkları iç çatışmaları kabul etmeye yanaşmazlar. Kendi yetersizliklerini gizlemede kullandıkları ve gerçek sandıkları benlik imajı onları 
olduklarından daha üstün görmelerine neden olur (Schultz ve Schultz, 2002: 581).

Nevrotikler idealize edilmiş bir imaj yaratarak sınırsız yetenek ve güç kazandıkları görüntüsü vermeye çalışırlar. Hayallerinde, kahramanlar, dâhiler, yüce âşıklar, azizler ve tanrılar haline gelirler. $\mathrm{Bu}$ görüntüler onlara temel çatışmalarıyla başa çıkmak için bir yol sağlar. Horney'e göre nevrotikler, dış dünyada başarı ve zafer kazanarak idealize edilmiş benliği gerçekleştirmeye çalışırlar (Ryckman, 2008: 160-161). Benliğin idealize edilmesinde nevrotik kişiler, çatışmalarda kullandıkları savunma stratejileri ile ilişkili olarak kendilerini farklı şekillerde yüceltirler. Buna göre; iyilik, cömertlik, doğruluk, dürüstlük, cana yakınlık, alçakgönüllülük gibi özellikler insanlara yönelen uysal tipin ideal benlik imgeleridir. İnsanlara karşı olan saldırgan tipin ideal benlik imgeleri diğer insanlardan daha zeki ve gerçekçi olma, her durumda kazanan kişi olma gibi özellikler taşır. İnsanlardan uzaklaşan yalıtkan tiplerin ideal benlik imgeleri ise, öz-yeterlilik, bağımsızlık, adil olma, arzulardan kurtulmuş olma, hazza ve acıya kapalı olma gibi özelliklerden oluşur (İnanç ve Yerlikaya, 2012: 99-100).

Horney, gerçek benlik ile ideal benlik arasındaki farkı açıklar. Buna göre gerçek benlik, "bütün insanların sahip olduğu, ancak her bireyde kendine özgü bir biçimde bulunan, insanın gelişiminin kaynağındaki güç" olarak tanımlanabilir (Cebeci, 2004: 240). Horney, ideal benlik imgelerinin sabit bir niteliğe sahip olduğunu dile getirir. İdeal benliğin nevrotikler tarafından ulaşılmak istenen bir hedeften ziyade taptıkları ya da saplantıya dönüştürdükleri bir görüş olduğunu söyler. Horney ayrıca, gerçek ideallerin dinamik yapısı gereği gelişmeye yönelik bir güç olmasına karşın, ideal benlik imgesinin gelişmeye engel bir nitelik taşıdığını belirtir (Horney, 1995: 79). İdealize ettiği benlik imajının gerçekliğine inanan nevrotikler, gerçek benlikleriyle temaslarını kaybederler. Kişi idealize ettiği benliği kendini değerlendirme standardı olarak kullanmaya başlar. Kendini gerçekleştirmek yerine, idealize ettiği benliklerini gerçekleştirmeye doğru hareket ederler. Horney, idealize edilmiş görüntünün kişide görkem arayışı, nevrotik talep ve nevrotik gurur şeklinde üç yönü olduğunu belirtir (Feist ve Feist, 2008: 181).

\subsection{Nevrotik Görkem Arayışı}

Nevrotik kişilerin çaresizlik, insanlara karşı kızgınlık ve insanlardan soyutlanma eğilimleri kendilerini koruma amacı taşır. $\mathrm{Bu}$ süreçte idealize ettikleri imge ile oluşturmaya çalıştıkları kimlik duygusuna yönelik çözümler görkem arayışını içerir (Geçtan, 1996: 256-257). Görkem arayışının, mükemmelliğe olan gereksinim, nevrotik hırs ve kinci zafer ihtiyacı olarak adlandırılan üç ögesi vardır (Feist ve Feist, 2008: 181). Horney bu öğelerin güç ve farkındalık açısından farklı seviyelerde herkeste olduğunu belirtir (Horney, 2015: 33).

En aşırı öge olarak tanımlanan mükemmelliğe olan gereksinim, kişiliğin bütünüyle idealize edilmiş benlik kalıbına aktarılmasıdır. Kişi bu amaca ulaşırken kendisine dayattığı bazı zorunluluklardan hareket eder. Ancak bunu yaparken kendi ruhsal durumunu göz ardı eder. Buradaki temel dayanağı ise hiçbir şeyin imkânsız olmadığını göstermektir. Görkem arayışındaki ikinci öğe olan nevrotik hırs, en dışa dönük ve açık öge olarak tanımlanır. Dış dünyaya karşı başarıya ulaşma dürtüsü olarak nevrotik hırs, abartılı bir üstünlük ve başarı arayışıdır. Ancak bu kişiler abartılı bir üstünlük ve başarıya sahip olduklarını düşünseler de bunu gerçekleştirmek için ulaşılması en kolay yolu seçerler. Dolayısıyla bu hırs yaşam içerisinde değişik şekillerde olabilir. Örneğin, bir kişinin okulda en başarılı öğrenci olmaya yönelik hırsı, onu daha sonraki yıllarda en iyi gösteri köpeklerini yetiştirmeye yönlendirebilir. Bir dönem savaş kahramanı olma hırsı gösteren bir kişi başka bir zaman en büyük aziz olma eğilimi gösterebilir. $\mathrm{Bu}$ değişimler kişinin kendisini kolayca aldatmasına neden olur. Diğer öğelerden daha yıkıcı olarak tanımlanan kinci zafer ihtiyacı, gerçek bir başarı ve üstünlük kazanmanın ötesinde karşıdakini utandırarak önem ve güç kazanmaktır. Ayrıca diğer insanları küçük düşürerek iktidar sahibi olma ve acı çektirme amacı taşır. Nevrotikler kazandıkları zaferlerden sonra herhangi bir vicdan azabı çekmezler ve her başarı, yenilgi korkularını artırır. Bu durum zafere olan ihtiyaçlarını sürekli güçlendirir (Feist ve Feist, 2008: 181-182; Horney, 2015: 33-36).

\subsection{Nevrotik Talepler}

Horney, görkem arayışındaki nevrotik kişilerin, kendilerince kurguladıkları sınırsız imkanlar içerisindeki bir hayal dünyasında savrulduklarını belirtir. Dışarıdan bakıldığında normal bir yaşam sürdüğü görülen bu kişilerin kendi kurdukları dünya ile dışarıdaki gerçeklik arasında bir uyuşmazlık oluşur. Nevrotikler bu uyumsuzluğu görmek yerine dış dünyanın bu hayal dünyasına uygun davranmasını bekler. Nevrotikler, başkalarının özel ilgisini ve hürmetini hak ettiklerine inanırlar. Kapsamlı bir talebin parçası durumundaki bu iddialar bazen oldukça görünür hale gelebilir. Nevrotikler içinde bulundukları bu probleme çözüm bulmak yerine diğerlerinin ona uygun davranıp kendisini rahatsız etmeyecek yolları bulmalarını beklerler (Horney, 2015: 51-52). Ancak nevrotiklerin diğer insanlara dayattığı ve gerçekçi olmayan bu talepler ve beklentiler, idealize edilmiş öz-imgeleriyle çok uyumlu olduğu için, özel ayrıcalık iddialarının mantıksız olduğunu görmelerini engeller (Ewen, 2003: 120-121).

Nevrotik talepler, normal ihtiyaçlar ve isteklerden farklıdır. Normal talepler yerine getirilmediğinde, insanlar anlaşılır bir şekilde hayal kırıklığına uğrarlar. Nevrotik talepler karşılanmadığında, nevrotikler öfkeli ve şaşkın olurlar (Feist ve Feist, 2008: 182). Diğer taraftan normal bir talep ile nevrotik bir talep arasındaki fark belirgin olsa da nevrotikler bu farkı hem görmezler hem de bunu görmeye isteksiz olurlar (İnanç ve Yerlikaya, 2012: 103).

Nevrotik taleplerin bir diğer özelliği benmerkezci olmasıdır. Nevrotikler kendi taleplerinin karşılanması konusunda diğerlerinin durumunu dikkate almazlar. Bir nevrotik, talepte bulunduğunda diğerleri ne işi varsa bırakıp onun talebini karşılamalıdır. Horney bu durumu çocuksu karakter özellikleri ile ilgili kuramsal temele dayanak olarak gösterir. Örneğin bir çocuk, annesinin de uyku ihtiyacı olduğu ya da bir oyuncak almak için yeterli parasının olup olmadığ durumuyla ilgilenmez. Nevrotikler kendilerinin herhangi bir gayret göstermeksizin taleplerinin karşılanmasını beklerler. Onlar sadece reddetmek veya kabul etmekten başka bir şey yapmak istemezler. Başkaları onlar için her şeyi düşünmeli ve yapmalıdır. Horney nevrotik taleplerin öç alıcı özelliğine de vurgu yapar. Nevrotik kişiler kendilerine karşı hatalı 
davranıldığını düşünerek misilleme yapmakta ısrarcı davranabilirler (Horney, 2015: 60-63).

\subsection{Nevrotik Gurur}

Horney, nevrotik kişilerin idealize edilmiş benlik imgesine ulaşma çabasının gurur sistemi olarak adlandırdığı bir olguyu ortaya çıkardığını savunur (Geçtan, 1996: 257). Horney'e göre nevrotikler mükemmel olmak için gösterdikleri tüm çabaya rağmen ihtiyaç duydukları özgüven ve haysiyeti elde edemezler. Kendilerini tanrısal bir varlık olarak hayal etmelerine karşın, sıradan bir kişinin özgüveninden bile yoksun olarak yaşarlar. Yüksek konumlara erişebilseler de bu durum onlara içsel bir güven sağlamaz. Kendisinin istenmeyen bir kişi olarak görüldüğüne inanır ve kolayca incinir. Değerli olduğunu hissettirecek dışarıdan gelecek teyitlere ihtiyaç duyarlar. Bu destekler geldiği sürece kendisini önemli ve güçlü hissederler ancak söz konusu destek kesildiğinde, başarısızlık yaşadığında ya da kendisiyle baş başa kaldığında çöküntü içerisine girerler (Horney, 2015: 101).

Gerçek özgüven, gerçekçi niteliklere ve başarılara dayanır. Genellikle sessiz bir itibarla ifade edilir. Öte yandan nevrotik gurur, idealize edilmiş bir benlik imajına dayanır ve genellikle kişinin kendisinin yüceltilmiş bir görünümünü korumak ve desteklemek için yüksek sesle ilan edilir (Feist ve Feist, 2008: 183). Nevrotik gurur; sağlıklı gurur veya özgüvenden niteliksel olarak farklıdır. Buna göre, idealize edilmiş benlik imgesiyle özdeşleşen görkem arayışındaki kişinin sahip olduğunu düşündüğü kişisel özelliklerine bağladığı abartılı ve irrasyonel gururdur. Horney nevrotik gururu, görkem arayışı ile başlayan sürecin mantıksal bir sonucu ve bu arayışın doruk noktası olarak değerlendirir (İnanç ve Yerlikaya, 2012: 101-102).

\section{Sinema ve Psikoloji}

Psikoloji bilimi, insan davranışlarının doğasını anlamaya yönelik bir bilim dalıdır. Buna karşın sinema, karmaşık insan davranışlarını tüm detayları ile perdeye aktaran bir sanat dalıdır. İnsan merkezli ve insan hayatına odaklanan bir sanat dalı olarak sinema, psikoloji biliminden yararlanmaktadır. Nitekim sinema, insanların duygusal ve zihinsel tecrübeleri sonucunda elde ettikleri kazanımları anlamlandırmada etkilidir (Büdün, 2018: 157).

İki farklı yönteme sahip iki farklı alan olarak psikoloji ve sinema birbirini besleyen bir rol de üstlenir. Sinemanın psikolojiden faydalanması, bilimsel temellendirme açısından önemlidir. İnsan psikolojisine dair bilimsel teoriler sinema filmleri için senaryo, karakter ve oyunculuk becerileri için bir kaynak teşkil etmektedir. Bir sanat dalı olarak yapılan üretimde sanatsal yeteneklerin yanında insan psikolojisi hakkında akademik bilgiler sanat ürününün hedefine yaklaşmasında önemli katkı sağlamaktadır. Diğer taraftan psikoloji bilimi de somutlaştırma ihtiyacını sinemanın görsel gücünden yararlanarak karşılamaktadır (Gençöz, 2009; Tümlü ve Acar, 2014: 62).

Sinema, toplumu yansitmanın yanı sira toplumu etkileme gücüne de sahip olabilmektedir. Wedding ve Niemiec (2003) filmlerin halkın zihinsel hastalık algısını, zihinsel hastalığı olan insanları ve bu bozuklukları tedavi eden profesyonelleri şekillendirme ihtimalinden bahseder. Bunun yanı sıra filmlerin eğitici etkisinin olumlu ve olumsuz olabileceğini belirtir. Rain Man filmindeki otistik adamın Amerikalıları bu durum hakkında eğitme noktasında olumlu etkisine örnek gösterir (Wedding, Niemiec, 2003: 207).

Çalışmada, psikoloji ve sinema arasındaki bu karşılıklı ilişkiden hareketle, psikanalitik yaklaşım çerçevesinde yapılacak bir çözümlemede filmlerin içerik malzemesi ve karakterleri psikanalitik veriler olarak değerlendirilmektedir. Kayı Kız filminin konusu ve filmin ana karakterinin yansıttığı davranışlar itibari ile nevrotik karakter çözümlemesi incelemesine uygun olduğu alanında uzman akademisyenlerden alınan görüşler doğrultusunda belirlenmiştir.

\section{Kayıp Kız (Gone Girl) Filminin Çözümlemesi}

Vizyon Tarihi: 10 Ekim 2014; Yönetmen: David Fincher; Oyuncular: Ben Affleck, Rosamund Pike, Neil Patrick Harris, Tyler Perry, Carrie Coon, Kim Dickens; Tür: Suç, Dram, Gerilim; Ülke: ABD; Y1l: 2014 (https://www.imdb.com/title/tt2267998/?ref_=nv_sr_1, http://www.beyazperde.com/filmler/film-217882/).

\subsection{Filmin Konusu}

Amerika'nın Missouri eyaletinde yaşamını sürdüren Nick ve Amy çifti evliliklerinin beşinci yıldönümünü kutlamaya hazırlandıkları sırada Amy aniden ortadan kaybolur. Polisi durumdan haber eden Nick, evdeki boğuşma izleri nedeniyle polisin şüphelendiği kişi olur. Ancak Amy’ye ne olduğuna dair herhangi bir fikri olmayan Nick'in kafası karışıktır. Olay medyaya da düşmüştür. Polis tüm aramalara rağmen Amy’i bulamaz. Dolayısıyla Nick'in üzerindeki baskı artar ve Amy'i öldürmüş olabileceği şüphesi oluşur. Amy’nin hayatta olup olmadığı ise tamamen belirsizdir (http://www.beyazperde.com/filmler/film-217882/, https://www.sinemalar.com/film/220827/gone-girl).

\section{2. Çözümlemede Kullanılacak Yöntem ve Temalar}

Çalıșma, Kayıp Kız (Gone Girl) filminin Karen Horney’in kişilik kuramından hareketle analiz edildiği betimsel bir çalışmadır. Betimsel analiz, çeşitli veri toplama teknikleri ile elde edilmiş verilerin daha önceden belirlenmiş temalara göre özetlenmesi ve yorumlanmasını içeren bir nitel veri analiz türüdür (Özdemir, 2010: 336). Çalışmada nitel araştırmalarda kullanılan veri toplama yöntemlerinden doküman incelemesi yöntemi kullanılmıştır. Doküman incelemesi, araştırılması hedeflenen olgu ya da olgular hakkında bilgi içeren yazılı ve görsel (film, video, fotoğraf vb.) materyallerin analizini kapsamaktadır. (Yıldırım ve Şimşek, 2000: 140-141). Doküman incelemesi yönteminde verilerin analizi çeşitli aşamalardan meydana gelmektedir. Bu aşamalar; analize konu olan uygun dokümanın seçilmesi, kategorilerin geliştirilmesi, analiz biriminin saptanmasıdır (Yıldırım ve Şimşek, 2000: 150-152).

Nitel araştırmalar doğası gereği nicel araştırmalardan farklı kriterlere göre değerlendirilir. Bu konuda çeşitli görüşler (ör. Guba 1981; Leninger, 1985; Sandelowski, 1986) ortaya konmuştur. Agar (1986) nitel araştırmalar için farklı bir dilin gerekliliğini öne sürer. Buna göre, nitel araştırmalarda güvenilirlik (reliability) ve geçerliliğin (validity) yerine, inandırıcılık (credibility), temsil doğruluğu (accuracy of representation) ve yazarin yetkisi (authorizy of the writer) gibi terimleri önerir (Krefting, 1990: 214-215). Bulguların doğruluğunu artırmak için bu stratejilerden bir ya da 
birkaçının kullanılması önerilmektedir. Güvenirliğin artırılması için çeşitli yöntemler vardır. Üye kontrolü (member checking), olumsuz durumların araştırılması ve alternatif açıklamalar (searching for negative cases and alternative explanations), hakem incelemesi (peer review) ve üçgenleme (triangulation)dir (Creswell, 2009: 192; Holloway ve Wheeler, 2010: 304-305).

Sosyal olguların nedenlerini açıklamaya dönük bir model, Miles ve Huberman (1994) tarafından öne sürülmüştür. Bu modele göre, sosyal olgular arasında, temellendirilebilir ve durağan sosyal olguları birleştirebilen bir düzene ve ardışıklığa sahip ilişkiler kurulabilir. Bu modele göre yapılan analiz: verilerin düzenlenmesi veya azaltılması, verilerin sergilenmesi, sonuçların tasvir edilmesi ve doğrulanması olarak tasarlanan üç temel aşamayı içermektedir (Miles ve Huberman, 1994: 10-12).

Şekil 1. Veri Analizinin Bileşenleri: İnteraktif Model

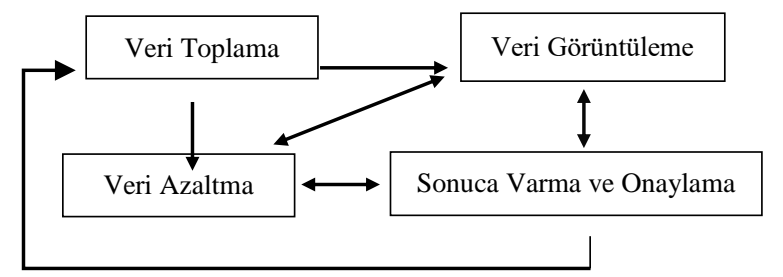

Kaynak: Miles \& Huberman (1994: 12)

Çalışmada verilerin toplanması için film tekrar izlenmiş ve tüm sahneler kontrol edilerek not edilmiștir. Horney'in nevrotik eğilimler yaklaşımında yer alan kavramlardan hareketle temalar oluşturulmuş ve temalara göre incelenecek sahneler seçilmiştir. Verilerin sunumu için veri seti, oluşturulan temalara göre gruplandırılmıștır. İlgili sahneler tablolarda temalara göre kodlanarak analiz edilmiştir. Verilerin analizinde alanında uzman akademisyenlerin görüşlerine başvurulmuştur.

Çalışmaya konu olan Kayıp Kız filmi, psikanaliz kuramcılarından Karen Horney'in nevrotik karakterlerin temel kaygıyla baș edebilmede kullandıklarını belirttiği "nevrotik eğilimler"den biri olan, "insanlara karşı olma eğilimindeki saldırgan tip" teması ile incelenmiștir. Ayrıca Horney'in, nevrotik eğilimlerin bir uzantısı olarak tanımladığı "idealize edilmiş benlik imgesi", "görkem arayışı" ve "gurur sistemi" temaları da çözümleme kapsamında ele alınmıştır. Çözümlemede kullanılan temalar; "temel kaygı", "nevrotik eğilimler -insanlara karşı olma eğilimindeki saldırgan tip", "idealize edilmiş benlik imgesi”, "görkem arayışı" ve "gurur sistemi" olarak belirlenmiştir. Buradan hareketle çalışmada, filmin geneli dikkate alındığında çözümlemeye konu olan temalara uygunluk açısından filmin ana karakterlerinden Amy Dunne (Rosamund Pike) karakterinin söz konusu kavramlarla ilişkili sahneleri değerlendirilmiştir. Söz konusu sahnelerin analizi aşamasında yapılan değerlendirmeler, alanında uzman iki akademisyenin de görüşü alınarak oluşturulmuştur.

\section{Bulgular ve Yorum}

5.1. Nevrotik Eğilimlerin Oluşumunda Temel Kaygının Kaynağı Olarak Ebeveyn-Çocuk İlişkisi

Filmde nevrotik eğilimlerin görünür kılındığı karakter olarak Amy Dunne karakteri karşımıza çıkmaktadır. Bu nedenle nevrotik eğilimlere sahip nevrotik karakter analizinde Amy Dunne karakteri değerlendirilmiştir. Film başlangıçta farklı karakterler üzerinden kurgulanmış gibi görünse de Amy karakteri tüm olayların merkezinde yer almaktadır.

Horney, kişiliğin biçimlenmesinde Freud'dan farklı olarak sosyo-kültürel faktörlerin, özellikle de çocukluk döneminde yaşananların önemini vurgular. Ebeveynlerin çocuklarıyla olan ilişkilerindeki ihmalkâr, aşırı korumacı, reddedici ya da Şımartıcı tutumların çocukların temel kaygı yaşamasına zemin oluşturabileceğini belirtir. (İnanç ve Yerlikaya, 2012: 91).

Tablo 1. Temel Kaygının Kaynağı Olarak Ebeveyn-Çocuk İlişkisi

\begin{tabular}{|c|c|}
\hline Tema & Sahne \\
\hline $\begin{array}{l}\text { Temel } \\
\text { Kayg1 }\end{array}$ & $\begin{array}{l}\text { Filmde Amy'nin çocukluk döneminde ailesiyle } \\
\text { kurduğu ilişkiye dair ilk bilgileri günlüğ̈̈ndeki } \\
\text { aktarımlarda görüyoruz. Amy için temel } \\
\text { kaygının oluşumundaki işaretler burada } \\
\text { karşımıza çımaktadır. Annesinin yazmış } \\
\text { olduğu "Muhteşem Amy" kitaplarına ilham } \\
\text { kaynağı olan gerçek Amy'nin hiçbir zaman } \\
\text { kitaptaki muhteşemliğe ulaşamadığını } \\
\text { görüyoruz. Düğ̈n konseptinde yapılan } \\
\text { "Muhteşem Amy" isimli kitabın lansmanında } \\
\text { Amy'nin kendisiyle ilgili "Amy çelloyu on } \\
\text { yaşında bırakırken Muhteşem Amy müzik } \\
\text { dehası olmuştur; Amy birinci sınıfta voleybol } \\
\text { takımından atılmışken Muhteşem Amy voleybol } \\
\text { takımının as oyuncusu seçilmiştir; Amy'nin bir } \\
\text { köpeği olmamışken, Muhteşem Amy'nin } \\
\text { olmuştur; Muhteşem Amy benden hep bir adım } \\
\text { önde olmuştur" sözlerinden temel kaygının } \\
\text { oluşumuna sebep olan eksiklik ve ilgisizlik } \\
\text { duygularını gözlemliyoruz. }\end{array}$ \\
\hline $\begin{array}{l}\text { Temel } \\
\text { Kayg1 }\end{array}$ & $\begin{array}{l}\text { Amy'nin çocukluk döneminde ailesiyle } \\
\text { yaşadığı ilişkideki sorunların daha sonraki } \\
\text { yaşantısında düşmanca bir davranışa } \\
\text { dönüştüğünü Nick'le evliliğinden önce Tommy } \\
\text { ve Desi Collings'le yaşadığı iki ilişkide } \\
\text { görebiliyoruz. Söz konusu iki kişi ile yaşadığ1 } \\
\text { ilişki sorunlu şekilde bitmiştir. }\end{array}$ \\
\hline
\end{tabular}

Horney'in kuramına göre, çocuğun ailesinde reddedici ya da küçük düşürücü tutumlarla karşılaşması kaygının gelişmesine katkı sağlar. İtici ya da küçük düşürücü davranışlara sosyal çevreyle beraber ailesinde de rastlaması kişide yıkıcı izler bırakır ve dış dünyaya karşı düşmanca duygular beslemesine neden olur (Geçtan, 1997: 87-88).

5.2. Nevrotik Eğilimlerin Bağlantısı ve Konumlanışı (İnsanlara Karşı Olma Eğilimindeki Saldırgan Tip)

Amy çocukluğunda yakalayamadığı mutluluğu Nick'le evliliğinde yakaladığına inanmıştır. Ancak bu mutluluk daha sonra yerini tekrar mutsuzluğa bırakmıștır. Filmde bu noktada Amy karakterinin nevrotik eğilimine dair konumlandırmalar karşımıza çıkmaktadır. Amy karakterinin davranışları, insanlara karşı olma eğilimindeki saldırgan tipin davranışları ile örtüşmektedir. Saldırgan tipin yöneleceği birçok nevrotik ihtiyacın filmde yer aldığ1 görülmektedir. 
Tablo 2. Nevrotik Eğilimlerin Bağlantısı ve Konumlanışı

\begin{tabular}{ll}
\hline Tema & Sahne \\
\hline & Filmde Amy'nin "inandırıcı bir cinayet \\
& izlenimi vermek disiplin gerektirir" \\
& sözüyle başlayan sahnede kendi sesinden \\
& planının tüm detayları uzun bir şekilde \\
& anlatılmaktadır. "Mahalleden bir salağı \\
& arkadaş edin" sözünde bahsettiği \\
& komşusu, Amy'nin başkalarını \\
& kullanmaya ve onlardan yararlanmaya \\
Nevrotik eğilim & yönelik nevrotik ihtiyacının açı \\
(İnsanlara karşı & göstergelerinden biridir. Söz konusu \\
olma eğilimindeki & komşusu hamiledir ve Amy'nin planında \\
saldırgan tip) & yer bulmaktadır. Yine Amy’nin "dikkatli \\
& bir şekilde suç mahallini düzenle ve birkaç \\
& hata yap ki, şüphe uyandırsın" sözüyle \\
& kusursuzca yazdığına inandığ1 \\
& senaryosunun detaylarını anlattığ1 \\
& sahneler kusursuzluğa ve yanılmazlığa \\
& duyulan nevrotik ihtiyacın bir \\
& göstergesidir.
\end{tabular}

Nick olayların içinden çıkılmaz bir hal almaya başlaması üzerine umutsuz davaların avukatı olarak tanınan bir avukatla anlaşır. Avukatla sorușturma detaylarını konuşurken Amy'nin geçmişte Tommy ve Desi Collings adındaki iki kişiyle yaşadı $\breve{g}_{1}$ ilişkilerden bahseder. Bu sahnede anlatılanlar Amy'nin insanlara

Nevrotik eğilim (İnsanlara karş1 olma eğilimindeki saldırgan tip) karş1 olma eğilimindeki düşmanca tavırlara örnek teşkil etmektedir. İnsanlara karşı olma eğilimindeki saldırgan tipler başkalarıyla sürekli kavga halinde olmakla beraber bu tutumlarını kentli ve soylu nezaketle gizleme eğilimi taşırlar. Nitekim Amy'nin geçmişte Tommy ve Desi Collings'e sonraları ise Nick'e yönelik düşmanca dürtüleri ve intikam hırsı başlangıçta benzer davranışlarla gizlenmiștir.

Horney'in dişsallaştırma olarak
tanımladığı ve diğer insanları sürekli sömürme eğilimi olarak açıklanan (Burger, 2006: 175) durumu, Amy'nin gizlendiği yerde paralarını kaptırması sonucu Desi Collings'e tekrar yaklaşmasında görmekteyiz. Amy yazdığı senaryoya Collings'i inandırır ve Collings süper lüks göl evinde onun gizlenmesine yardımcı olur. Amy tüm imkânların olduğu lüks göl evinde Collings'in evde olmadığı bir gün yeni planının hazırlıklarını yapar. Collings geldiğinde ise planını devreye koyar ve tecavüze uğramış görüntüsü vererek bir cinayet işler. Kendisine yardımcı olan bir kişiyi kullanarak başkalarını kullanmaya yönelik nevrotik ihtiyacın bir başka örneğini gösterir. Amy burada insanlara karşı olma eğilimindeki kişilerin kendi amaçlarına ulaşmak için her şeyi yapabileceğinin hatta bir insanı gözünü kırpmadan öldürerek çaresizliği devre dışı bırakan saldırgan tipin bir örneği olarak karşımıza çıkmaktadır.
Horney'e göre, nevrotik karakterler kendilerini güçlü ve başarılı bulmalarına rağmen kendilerini güvende hissetmezler. Nitekim Amy'nin tecavüze uğramış ve şiddete maruz kalmış bir şekilde kendiliğinden ortaya çıktığı ve sonrasında hastanede polislere ifade verdiği sahnede dedektif Rhonda onun hikâyesindeki
Nevrotik eğilim (İnsanlara karşı olma eğilimindeki saldırgan tip)

Nevrotik eğilim (İnsanlara karşı olma eğilimindeki saldırgan tip) gariplikleri fark eder. Ancak Amy bitkin görüntüsünü de kullanarak konuyu değiştirmek istediğini söyler. Dedektif Rhonda ifadelerdeki çelişkileri yakaladıkça Amy sinirlenir ve ağır ifadeler kullanarak konuyu değiştirir. Bu örnek, nevrotik kişilerin güvenliği tehlikeye düştüğü zaman ortaya çıkan büyük korkuyu açıklar. Bu kişiler nevrotik ihtiyaçlarını karşılayan standartlardan sapma olması durumunda her șeyini kaybedeceğine inanır. (Horney, 1991: 35).

Amy'i ortaya çıktığında halk, onun mağdur ve masum olduğunu düşünür. Ancak Nick onun yalanlarına inanmamaktadır. Nick, bir cinayet işlediğini hatırlatmasına karşılık Amy'nin kendisinin bir savaşçı olduğunu ve kocasına dönebilmek için önüne çıkanlarla savaştığını söylemesi insanlara karşı olan saldırgan tipin yaşamı amansız bir mücadele olarak görmelerinin bir yansıması olarak karșımıza çıkmaktadır. Nick'in kendisini terk etme restine karşılık Amy, bunun akillica bir hareket olmayacağını, yaralı ve tecavüze uğramış olmasına rağmen kocasına dönen eşini terk edecek bir kişinin toplumda öfkeyle karşılanacağını ve bu acıların unutulmaması için de kendisinin elinden gelen her şeyi yapacağını söylemesi yine saldırgan tiplerin bariz intikam duygusunun bir göstergesidir.

\subsection{Amy Karakterinin İdealize Edilmiş Benlik İmgesi ve Görkem Arayışı}

İdealize edilmiş benlik imgesi, kişinin kendisine yabancılaştığ 1 kendi gerçek benliğinden uzaklaştığ yanıltıcı bir maske niteliği taşır (Schultz ve Schultz, 2002: 581). Bu kişiler tehlikeye karşı aşırı hassas davrandıkları için birçok şeyi tehlike olarak algılar. Bu sebeple algılarında bir daralma meydana gelir. Oluşturdukları benlikle gerçeklik arasındaki uyuşmazlığ 1 fark edemezler. Kişinin kendisine yabancılaşmasının bir sonucu olarak güvenlik sağladığını zannettiği davranışlarını değiştirmeye yanaşmazlar (Geçtan, 1997: 150). 
Tablo 3. İdealize Edilmiş Benlik İmgesi ve Görkem Arayışı

\begin{tabular}{|c|c|}
\hline Tema & Sahne \\
\hline $\begin{array}{l}\text { İdealize Edilmiş } \\
\text { Benlik İmgesi }\end{array}$ & $\begin{array}{l}\text { Amy, insanlara karşı olma eğilimindeki } \\
\text { saldırgan nevrotik karakterlerde görülen } \\
\text { güçlü, başkalarından daha zeki, her } \\
\text { durumda kazanan kişi olduğuna inandığı } \\
\text { bir benlik imgesi oluşturmuştur. Bunun } \\
\text { örneğini Nick'in öğrenci sevgilisi } \\
\text { Andie'nin televizyona çıkarak } \\
\text { yaşadıkları yasak aşkı bizzat açıklamas } \\
\text { sahnesinde görmekteyiz. Basın } \\
\text { açıklaması ekrandan izleyen Amy, } \\
\text { Andie'nin kıyafetindeki masumiyete } \\
\text { takılır ve neden bebek bakıcısı gibi } \\
\text { giyindiğini sorgular. Amy, "Bir rahibe } \\
\text { kllığına girmediği kalmış" sözüyle } \\
\text { Andie'nin dürüstlüğünün altındaki } \\
\text { ahlaksızlığa vurgu yaparken kendi } \\
\text { durumunun farkında değildir. }\end{array}$ \\
\hline $\begin{array}{l}\text { İdealize Edilmiş } \\
\text { Benlik İmgesi }\end{array}$ & $\begin{array}{l}\text { Nevrotik kişilerin ulaştıklarına } \\
\text { inandıkları benlik imgesine rağmen içsel } \\
\text { güven hissetmedikleri durum olarak } \\
\text { adlandırılan gurur sistemi polisin Amy'in } \\
\text { ifadesini aldığ s sahnede karşımıza } \\
\text { çıkmaktadır. Hikâyeyi inandırıcı } \\
\text { bulmayan Dedektif Rhonda'nın sorusuna } \\
\text { cevaben "Akıl sağlığı yerinde olmadığı } \\
\text { bilinen bir adam tarafindan esir } \\
\text { alındı̆ğm hikâyeye geri dönebilir } \\
\text { miyim?" sözünde Amy'nin yaşadığı içsel } \\
\text { güvensizliği görmek mümkündür. }\end{array}$ \\
\hline
\end{tabular}

Görkem arayışının bir öğesi olan kinci zafer ihtiyacına yönelik bir örneği, Amy'nin cinayet görüntüsü vermeye çalıştığı kaybolma planı için eşinin kendisine gösterdiği tavrı bir intikam yöntemi olarak kullanacağı mesajında görmekteyiz. Amy, Missouri'ye taşınırken eşinin kendisini yanına yanlışlıkla aldığı ve gerektiğinde atabileceği bir yük gibi gördüğünü düşünmektedir. Amy'nin "yok olabilirmişim gibi geliyor" sözleri intikam yönteminin bir izahı gibi durmaktadır. Yine Amy kocasının kendisini tüketene kadar her şeyini çaldığını söyler. Ayrıca şeref, gurur, umut ve para birakmadığından yakınmaktadır. Bunun cinayet olarak adlandırılması gerektiğini düşünerek "ceza suça denk olmall" sözleriyle görkem arayışındaki insanların kinci zafer ihtiyacına denk düşen bir durum sergilemektedir.

Görkem arayışının en yıkıcı öğesi olan kinci zafer ihtiyacının motive edici gücü geçmişte yaşanan hayal kırıklıklarının ve aşağılanmanın öcünü almaya yönelik dürtülerdir (İnanç ve Yerlikaya, 2012: 101). Amy’nin "Beni yok edip sonsuza dek mutlu yaşamasina izin mi Görkem Arayışı verecektim? Hayatta olmaz. O kazanmayı hak etmedi. Benim tatll, sevimli Missouri'li delikanlım. Dersini almast icap ediyordu" sözlerinde nevrotiklerdeki görkem arayışının en y1kıcı öğesi olan kinci zafer ihtiyacı örneği görülmektedir.
Filmde Amy'nin kinci zafer ihtiyacına bir başka örneği Nick'in avukatla yaptığı konuşmada görmekteyiz. Nick, Amy için en önemli şeyin insanlara ders vermek olduğunu söyler. Andie'yle onu aldattığ için sahte bir cinayet kurguladığını ve ipuçlarını onu aldattığı yerlere koyarak iyice yüzüne vurmaya çalıştığını belirtir. Nitekim kinci zafer ihtiyacında asıl amaç başarının kendisinden ziyade başarıyla başkalarını utandırmak, küçük düşürerek acı çektirmektir.

Filmin finalinde Amy'nin kinci zafer ihtiyacının ulaştığı nokta ve Nick'e karşı elde ettiği zafer karşımıza çıkmaktadır. Nick'le Amy arasında fütursuzca bir tartışma geçer. Amy kolay pes etmeyeceğini ve Nick'e kendisi için adam öldürdüğünü belirtir. Karşısındaki insanı çaresiz bırakacak şu sözleri söyler: "Kim senin için böyle bir şey yapar? Köylü bir kizla mutlu olabileceğini mi sanıyorsun? Hayır yavrum. Seni ancak ben paklarım." Nitekim Nick yenilgiyi kabul eder ve ekranlarda Amy ile beraber mutlu çift görüntüsü veren bir konuşma ile film son bulur.

\section{Sonuç}

İnsanlar yaşamları boyunca çok sayıda zorlukla karşılaşır. Normal insanlar bunlarla baş etmek için bir takım yöntemler geliştirir. Başlangıçta başarılı olamazlarsa daha sonra başka yöntemler geliştirerek çoğunlukla sorunların üstesinden gelmeyi başarırlar. Başarısız oldukları zamanlarda da bununla yüzleşerek gerekli çıkarımları yaparlar. Ancak nevrotikler için durum böyle olmamaktadır. Nevrotikler bu durumlarda insanlara karşı düşmanca davranışlar sergiler ya da tam zıddı olarak insanlara daha fazla yönelerek onlara sığınmaya çalışırlar. Bir üçüncü yol olarak da kendilerini hayattan ve insanlardan uzak tutacak bir yalıtılmışlık içerisine girerler. $\mathrm{Bu}$ tutumlarının mantıkdışı ve uyumsuz niteliğinin farkında olsalar da görmezden gelirler (Geçtan, 1997: 149-150).

Sinema filmleri, psikoloji kuramlarına örnek teşkil etmesi ve kuramsal bilginin somutlaştırılmasında kullanılmaktadır. Sinema filmleri bu açıdan bir araç niteliği de taşımaktadır (Boyacı ve İlhan, 2016: 742). Çalışma bu bağlamda Kayıp Kız filmi üzerinden Horney'in nevrozlar ve insan gelişimine yönelik oluşturduğu kuramın somutlaştırılmasına örnek teşkil etmektedir. Nitekim alanyazına bakıldığında psikoloji kuramlarından hareketle film analizi içeren çeşitli çalışmalar mevcuttur. Miller (1999) Siradan Insanlar (Ordinary People), filmini depresif bir çocuğun tedavisinin tasvir edildiği bir film olarak değerlendirmiş̧tir. Erikson (1976) ise, İsveçli yönetmen Ingmar Berkman'ın Yaban Çilekleri (Wild Strawberries) filmini psikososyal gelişim kuramını açıklamada kullanmıştır (Morsünbül, 2015: 182). Durak ve Fışıloğlu (2007) aile terapisi kuramının uygulamasını örneklendirme amaciyla Annem Ŭgruna (One True Thing) filminin; Turan (2013) ise, Lacancı psikanalitik yaklaşım çerçevesinde Киуи filmindeki arzu kavramının çözümlemesini yapmıştır.

Bu çalışmada Kayıp Kız (Gone Girl) filminin, Horney'in psikanalitik yaklaşımı çerçevesinde nevrotik ihtiyaçlar çözümlemesi yapılmıştır. Filmde nevrotik bir karakter olarak 
incelediğimiz Amy Dunne, karşılaştı̆̆ sorunlarla mücadelede insanlara karşı olma eğiliminde düşmanca davranışlar gösteren saldırgan kişiliğe denk düşmektedir. Amy'nin çocukluk döneminde ailesiyle yaşadığı sorunlu ilişkide nevroz gelişimine zemin hazırlayan temel kaygıyı görmek mümkündür. Nitekim daha sonraki dönemlerde karşılaştığı insanlarla ilişkilerinde farklı yöntemler kullanarak düşmanca tutumlar geliştirmeye devam etmiştir.

Filmde Amy, nevrotik ihtiyaçlar olarak tanımlanan ve insanlara karşı olma eğilimindeki kişilerde görülen, nevrotik güç ihtiyacı, başkalarını kullanmaya ve onlardan yararlanmaya yönelik nevrotik ihtiyaç, kişisel başarı kazanmaya yönelik nevrotik ihtiyaç, kusursuz olmaya ve eleştiriye karşı savunmaya yönelik nevrotik ihtiyaç gibi nevrotik eğilimli davranışlar göstermektedir. Amy karakterinde ayrica, herkesi potansiyel olarak düşman görmek, çaresizliği devre dışı bırakmak, kavga ve savaşı kendi yapısının doğal bir parçası haline getirmek gibi insanlara karşı olma eğilimine sahip saldırgan kişiliğe ait özellikleri görmek mümkündür.

Amy, yaşamı boyunca insanlara karşı her durumda kazanan ve herkesi zekâsılla yenebileceğini sandığı bir benlik imgesi oluşturmuştur. Kendisiyle özdeşleştirdiği bu imgenin itkisiyle görkem arayışının kinci zafer ihtiyacına dönük eylemlerini gerçekleştirmiştir. Amacına ulaşmak için hayata geçirdiği planda bunun ayrıntıları görülmektedir. Kendisine haksızlık yapıldığı düşüncesiyle eşinden nevrotik hak talebinin kinci yapısı ile intikam almıştır. Bunu gerçekleştirirken herkesi ve her şeyi kendi çıkarı için kullanmıştır.

Filmde incelenen Amy karakterinin, Horney'in kuramı çerçevesinde nevrotik eğilimlerle örtüşen davranışlar sergilediği çok sayıda sahnenin bulunduğu sonucuna varılmıştır. Kayıp Kız filmi, nevrotik eğilimlerin, kişilerin davranışları ve diğer insanlarla iletişimi üzerindeki etkileri konusunda sinema ve psikolojinin odaklandığ $\breve{1}_{\text {bir }}$ ortak nokta örneği teşkil etmektedir. Film, kişilik kuramları çerçevesinde psikanalitik yaklaşımla ele alındığından alana katkı sunacak bilimsel temele dayanan bir çalışma niteliği taşımaktadır. Buradan hareketle çalışmanın psikanalitik yaklaşım çerçevesinde diğer kişilik kuramları ve farklı sinema örnekleri üzerinden yapılacak yeni çalışmalara katkı sunması beklenmektedir. Daha sonra yapılacak çalışmalarda gerek diğer psikanaliz kuramları çerçevesinde yapılacak analizlerle gerekse de oyunculuk, kurgu vb. teknik özellikler üzerinden elde edilecek bulgular geniş çerçevede bir değerlendirme firsatı oluşturabilir.

\section{Kaynakça}

Boyacı, M. \& İlhan, T. (2016). Bilişsel Davranış̧̧ı Terapi Yaklaşımının Film Analizi Yöntemiyle İncelenmesi, Mersin Üniversitesi Eğitim Fakültesi Dergisi, 12(2), 734-746.

Büdün, E. (2018). Milyoner (Slumdog Millionaire) Filminin Sosyal Bilişsel Kuram Çerçevesinde Çözümlenmesi, Akdeniz Üniversitesi Illetişim Fakültesi Dergisi, (29), 151-164.

Budak, S. (2000). Psikoloji Sözlüğü, Ankara: Bilim ve Sanat Yayınları.
Burger, J. M. (2006). Kişilik, İ. D. Erguvan Sarıŏlu (Çev.). İstanbul: Kaknüs Yayınları.

Cebeci, O. (2004). Psikanalitik Edebiyat Kuramı, İstanbul: İthaki Yayınları.

Coolidge, F. L. vd. (2001). On The Relationship Between Karen Horney's Tripartite Neurotic Type Theory And Personality Disorder Features, Personality and Individual Diferences, 30, 1387-1400.

Creswell, J. W. (2009). Research Design Qualitative, Quantitative and Mixed Methods Approaches, Third Edition, Sage Publications.

Doruk, E. K. (2015). İknanın Sosyal Psikolojisi, İstanbul: Derin Yayınları.

Durak, E. Ş. \& Fışıloğlu, H. (2007). Film Analizi Yöntemi ile Virginia Satir Aile Terapisi Yaklaşımına Bir Bakıș, Türk Psikoloji Yazıları, 10 (20), 43-62.

Erikson, E. H. (1976). Reflections on Dr. Borg's Life Cycle, Daedalus, (2), 1-28.

Ewen, R. B. (2003). An Introduction to Theories Of Personality, Sixth Edition, London: Lawrence Erlbaum Associates.

Feiring, C. (1983). Behavioral Styles in Infancy and Adulthood: The Work ofKaren Horney and Attachment Theorists Collaterally Considered, Journal of the American Academy of Child Psychiatry, 22(1), 1-7.

Feist J. \& Feist G. J. (2008). Theories of Personality, 7th Edition, New York: McGraw-Hill Education.

Friedman, H. S. \& Schustack, M. W. (2016). Miriam W., Personality Classic Theories and Modern Research, Sixth Edition, Boston: Pearson.

Geçtan, E. (1996). Psikanaliz ve Sonrası, 7.Baskı, İstanbul: Remzi Kitabevi.

Geçtan, E. (1997). İnsan Olmak, 18.Bask1, İstanbul: Remzi Kitabevi.

Geçtan, E. (2003). Psikodinamik Psikiyatri ve Normaldıșı Davranışlar, İstanbul: Metis Yayınları.

Gençöz, F. (2009). Sinema ve Psikoloji, Sekans Sinema Kültürü Dergisi, erișim adresi http://sekans.org/tr/arsiv/yazarlarimizdan/158sinema-ve-psikoloji Erişim Tarihi: 20.02.2020.

Holloway, I. \& Wheeler, S. (2010). Qualitative Research in Nursing and Healthcare, Third Edition, WileyBlackwell.

Horney, K. (1999). Çă̆ımızın Nevrotik Kişiliği, (Çev. S. Koçak). 4.Baskı, Ankara: Öteki Yayınları.

Horney, K. (1991). Kendi Kendine Psikanaliz, (Çev. S. Budak). 3.Baskı, Ankara: Öteki Yayınları.

Horney, K. (2015). Nevrozlar ve Insan Gelişimi, (Çev. E. Erbatur). 2.Bask1, İstanbul: Sel Yayıncılık.

Horney, K. (1994) Psikanalizde Yeni Yollar, (Çev. S. Budak). Ankara: Öteki Yayınevi. 
Horney, K. (1995). Ruhsal Çatışmalarımız, (Çev. S. Budak). Ankara: Öteki Yayınları.

İnanç, B. Y. \& Yerlikaya E. E. (2012). Kişilik Kuramları, 6.Bask1, Ankara: Pegem Akademi.

Kayıp Kı (Gone Girl). Erişim adresi http://www.imdb.com/title/tt2267998/?ref_=nv_sr_1 Erişim Tarihi: 12.08.2018.

"Kayıp Kı (Gone Girl)" Erişim adresi http://www.beyazperde.com/filmler/film-217882/ Erişim Tarihi: 12.08.2018.

"Kayıp K1z (Gone Girl)" Erişim adresi http://www.sinemalar.com/film/220827/gone-girl Erişim Tarihi: 12.08.2018.

Kiraz, S. (2015). Kitle, Kültür, Bunalım ve Yabancılaşma, Mavi Atlas, 5, 126-147.

Krefting, L. (1991). Rigor in Qualitative Research: The Assessment of Trustworthiness, The American Journal of Occupational Therapy, March, Volume 45, Number 3, 214-222.

Miles, M. B. \& Huberman A. M. (1994). Qualitative Data Analysis: An Expanded Sourcebook, Second Edition, California: Sage Publications.

Miller, F.C. (1999), Using The Movie Ordinary People To Teach Psychodynamic Psychotherapy With Adolescents, Academic Psychiatry, (23), 174-179.

Morsünbül, Ü. (2015). Bal, Süt ve Yumurta Filmlerinin Erikson'un Psikososyal Gelişim Kuramı Açısından Analizi, Illköğretim Online, 14(1), 181-187.
Özdemir, M. (2010). Nitel Veri Analizi: Sosyal Bilimlerde Yöntembilim Sorunsalı Üzerine Bir Çalışma, Eskişehir Osmangazi Üniversitesi Sosyal Bilimler Dergisi, 11(1), 323-343.

Ryckman, R. M. (2008). Theories of Personality, Ninth Edition, Belmont: Thomson Wadsworth Learning.

Schultz, D. P. \& Schultz, S. E. (2002) Modern Psikoloji Tarihi, (Çev. Y. Aslay). 2.Baskı, İstanbul: Kaknüs Yayınları.

Shatz, S. M. (2004). The Relationship Between Horney's Three Neurotic Types And Eysenck's PEN Model Of Personality, Personality and Individual Differences, 37, 1255-1261.

Turan, M. O. (2013). "Kuyu Filmindeki Arzu Kavramının Lacancı Psikanalitik Yaklaşım Çerçevesinde Çözümlenmesi”, Selçuk İletişim, 7(4), 169-185.

Tümlü, G. Ü. \& Acar, N. V. (2014). “Issız Adam” Filminin Gerçeklik Terapisine Dayalı İncelenmesi, Insan\&Insan Sayı 2, Güz, 62-73.

Wedding D. \& Niemiec, R. M. (2003). "The Clinical Use of Films in Psychotherapy”, Psychotherapy in Practice, Vol. 59(2), 207-215.

Yavuzer, N. (2013). İnsanın Saldırgan ve Yıkıcı Doğasını Anlamak, İstanbul Ticaret Üniversitesi Sosyal Bilimleri Dergisi, (12)23, Bahar, 43-57.

Yıldırım, A. \& Şimşek, H. (2000). Sosyal Bilimlerde Nitel Araştırma Yöntemleri, 2.Baskı, Ankara: Seçkin Yayınc1lik. 